\title{
COASTAL LINE CHANGES IN MEDITERRANEAN CITIES: MAN OR NATURE?
}

\author{
PEDRO MARCET LLORENS, JOSÉ NAVARRO PEDREÑO \& JESÚS M. SORIA MINGORANCE \\ Universidad Miguel Hernández de Elche, Universidad de Alicante, Spain
}

\begin{abstract}
Despite being a relatively stable sea compared to the great oceans, the Mediterranean is not a risk-free place of changes in the coast, both anthropogenic and natural. The coast is home to a large part of the population and cities which are generally in constant growth due to the quality of life and the possibilities offered (i.e. tourism and other activities linked to the sea). In Mediterranean coastal cities, the first maritime line is usually the one with the highest economical value and, where the space is used intensively. For this reason, land managers have developed strategies to occupy the maximum extension of the coast. Some of these are new uses for old port areas, take advantage of coastal containment works, extending the beaches mean artificial regenerations, the construction of breakwaters and, adding waste materials in order to increment the land, gain it to the sea. So that, the urban coastal lines of Mediterranean cities have been changing a long time. This work presents these changes in the past years (last 60 years) through a methodology based on the comparison of aerial photography from different times (1956-1957 and PNOA 2014-2016) in the following settlements of the South-East of Spain: Alicante, El Campello, Santa Pola, Torrevieja, Altea and Villajoyosa). The changes have been categorized so that we can quantify the type and proportion of the changes and discriminate if those are natural or artificial. The results showed that most of the municipalities have registered changes, those were due to land reclaimed to the sea and man is the main driver of this change. These changes mask and correct those due to natural erosion, soil loss or geological changes in the coastline.
\end{abstract}

Keywords: Mediterranean coastal, aerial photography, PNOA, land cover, coastline.

\section{INTRODUCTION}

The Mediterranean is a stable coast. The tides and waves are usually lower than ocean coasts [1], affording the urbanisation with moderate risks for the infrastructures and people activities. However, the Mediterranean cost is not a risk-free place. Occasionally the coastal municipalities suffer the consequences of coastal storms [2], especially on beaches and promenades [3]. On the beaches, the usual consequences are the erosion of the sand, and the progressive reduction of their area. On the promenades, the coastal storms induce damage to infrastructures.

More than $60 \%$ of the world's population resides in coastal regions [4]. These regions are attractive and have specific natural resources and economic activities [5]. The effects on the coastline and beaches have been very different before and after of the tourism development. A substantial part of human pressure on Mediterranean coasts is caused by tourism [5]. Before the tourism and tertiary sector development, the people need raw materials and energy sources for the industrial activities, which they got from the wood in the forests. The forests in the mountains were cut down progressively, also for the crops availability, because the agriculture was the main economic activity in those years [6]. The felling caused the deforestation, erosion and input of materials on the coast. Those inputs of sediments on the coast caused a big increase of the sedimentary coast at expense of the previous flooded areas [7], and the formation of large sandbars on low areas of the Alicante province coast. An example of that would be the sand areas in Guardamar del Segura, Elche and Santa Pola (dunas de Guardamar, dunas de el Pinet, Arenales del Sol). 


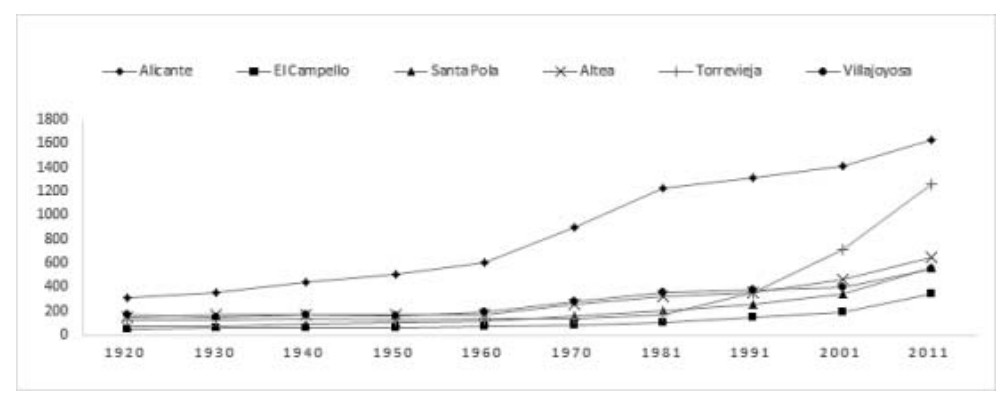

Figure 1: Population density in some municipalities of the Alicante Province. (Source: Instituto Nacional de Estadística (INE).)

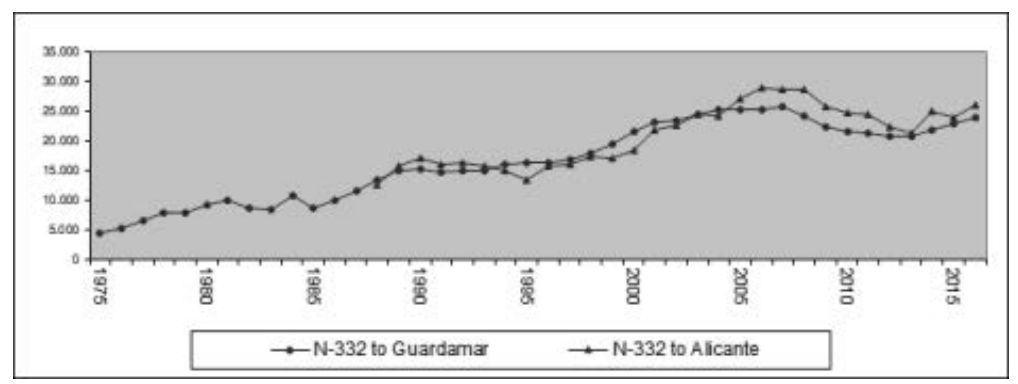

Figure 2: Annual Average Daily traffic (AADT) on N332 road, in access to Santa Pola. (Source: Ministerio de Fomento.)

The dune formations became a big problem in Guardamar del Segura, where the dunes threatened to bury the village. Fortunately, the Engineer Francisco Mira Botella [8], stabilized the dunes with diverse types of vegetation. After the tourism and service sector development, the trend on the coasts and basins is the opposite. In that period, there was a progressive transfer from agricultural use to other uses [5]. The great urbanisation process [9] and new irrigation agriculture needed water resources [10]. The wood from trees was not so important in the new forms of production [8], [11]. So, the mountains were progressively reforested. This combination of factors caused the opposite effects on the river basins. The previous crops reforestation [12] and water reserve infrastructures retained the erosion and transport of sediments to the coast. Since then, many areas on the coast are in regression because there is no new contribution of sediments. Therefore, the inland changes can cause important effects on the coast [7].

The urbanisation process was linked to a big growth of the population (Fig. 1). The railway construction in 1858, and later, of the airport in 1967, contributed in the arrival of lots of tourist and new population in the coast. Moreover, the number of vehicles was increasing by the time (Fig. 2). There were radical changes in urban structure and the growing demand of tourism and traffic infrastructures [5].

The coastline emplacement can change over time, especially on the sandy beaches. Most of the changes happened in the coast are caused, to a greater or lesser extent, by human 
influences on the coast or on the inland. Nevertheless, some changes have been carried out wilfully, and other, are the consequences unintentional from any activity or change in the land. The objective of this paper consists to know the causes of the changes on the coastline emplacement, especially, what part of the changes is due to intentional human actions.

\section{METHODS}

\subsection{Spatial and temporal scope}

Six coastal municipalities of the Alicante province have been selected for this study: Alicante $\left(0^{\circ} 28.86^{\prime} \mathrm{W}, 38^{\circ} 20.71^{\prime} \mathrm{N}\right)$, El Campello $\left(0^{\circ} 23.67^{\prime} \mathrm{W}, 38^{\circ} 25.71^{\prime} \mathrm{N}\right)$, Santa Pola $\left(0^{\circ} 33.31^{\prime} \mathrm{W}\right.$, $\left.38^{\circ} 11.40^{\prime} \mathrm{N}\right)$, Torrevieja $\left(0^{\circ} 41.33^{\prime} \mathrm{W}, 37^{\circ} 58.51^{\prime} \mathrm{N}\right)$, Altea $\left(0^{\circ} 02.93 \mathrm{WO}, 38^{\circ} 35.97^{\prime} \mathrm{N}\right)$ and Villajoyosa $\left(0^{\circ} 13.96^{\prime} \mathrm{W}, 38^{\circ} 30.35^{\prime} \mathrm{N}\right)$ and, their location in the province is represented in the Fig. 3. The used coordinate system is ETRS89 UMT zone 30. These municipalities have been selected to collect information from the north to the south coast of the province. The period analysed comprises from 1956 to 2014 . The marine area is characterised by its stability compared to oceanic areas, especially in Santa Pola, where the urban area is protected from the waves by a bay [2], [13]. That period represents a great tourism development in the Alicante province.

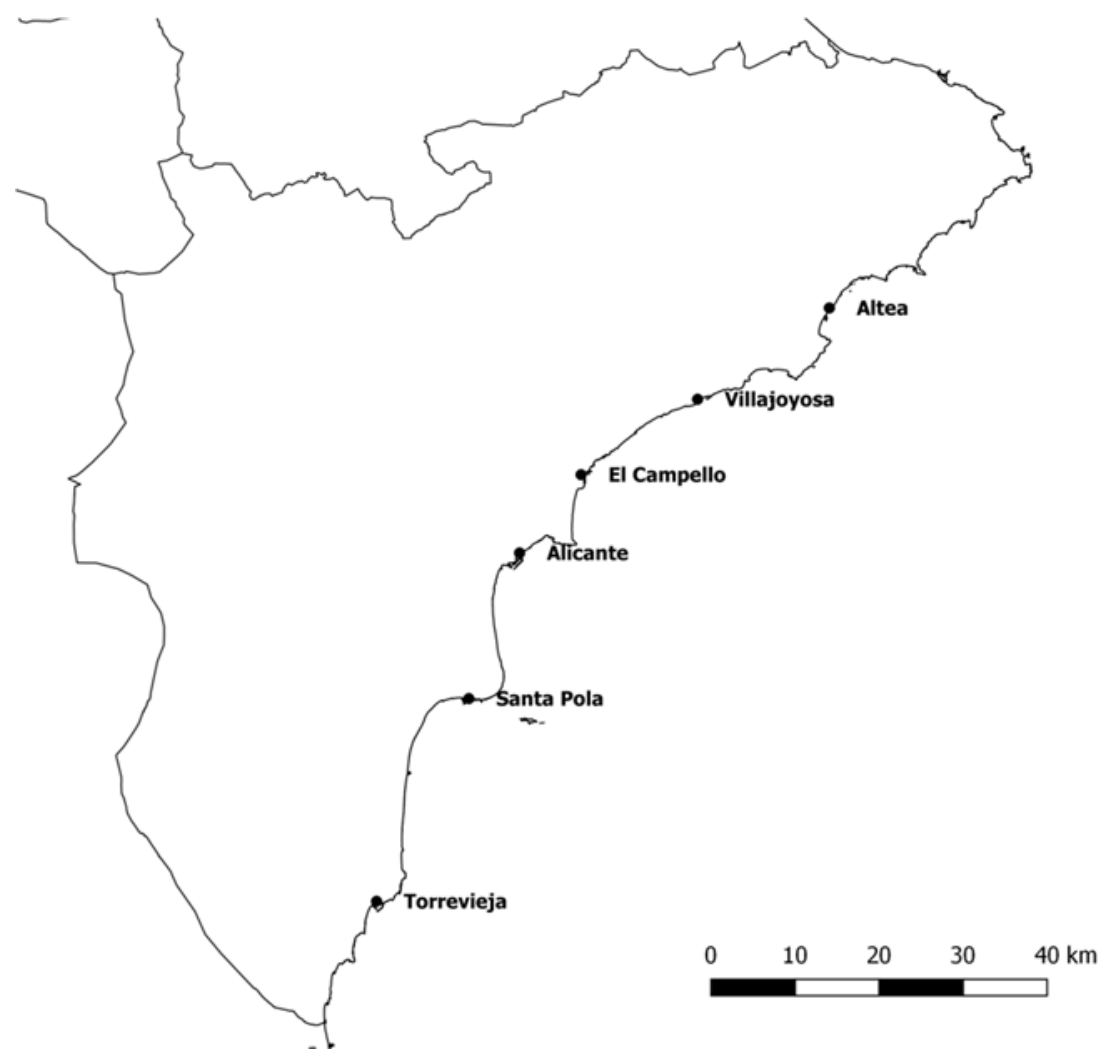

Figure 3: Location of the selected municipalities in the Alicante province. (Source: CNIG, Instituto Geográfico Nacional (IGN).) 


\subsection{Cartographic process}

To make the comparison between different times on the coastline, there are diverse methods that have been used previously. Some of these methods are GPS use, topographic systems use, GIS analysis (Geographic Information System), remote sensing and aerial photo interpretation, etc. [3]. There are diverse methods to check and follow up the sea level and global warming effects. Some of these would be the oceanographic buoys use, GDEM (Global System Elevation Model), mathematic model series, etc. [3]. It is common to combine diverse tools in the same project as in [14], which combined the cartographic land cover with GDEM systems to analyse the vulnerability in a study area.

In this case, the aerial photo interpretation from two different moments, and land cover cartography are used, but self-made in order to get the most up-to-date land cover, because the coast characteristics can change quickly. Moreover, than land cover change was associated to the process type (artificial or natural). This corresponds with the main objective.

\subsubsection{Preparing aerial photography}

The aerial photography used have been the historical corresponding to the years 1956-1957 (called Vuelo Americano serie B and actual orthophotography from PNOA (Plan Nacional de Ortofotografia Aérea), ) from years 2014-2016 [15]. All of them are available using the Web Map Service (WMS) layers from the National Geographic Institute of Spain (IGNC) free accessed open data). The first step of the work has been digitalising two both coastlines (1956 and 2014). The free software QGIS $^{\circledR} 2.18$ (from qgis project: www.qgis.org/es/site/index.html) was used to complete the coastal line and determine the coastal line and changes.

The scale of the WMS for 1956 photography is approximately 1:32,000, whereas each photo sheet has an area around $0.7 \mathrm{~km}^{2}$ and a pixel equivalent to $1-2 \mathrm{~m}^{2}$. In PNOA orthophotography, the pixel size was equivalent to $0.25 \mathrm{~m}$ to $0.50 \mathrm{~m}$ and the scale from $1: 5000$ to $1: 10,000$ [15].

\subsubsection{Cartography of changes}

Once digitalised the two both coastlines (1965 and 2014), the spaces where do not match two both coastlines were transformed into polygons. These polygons are subsequently divided and classified, according to their characteristics, to individualize spatial units with the same characteristics regarding to land cover and change processes. In order to understand the land cover, classifications derived from the Corine Land Cover were used, but self-made according to aerial photo interpretation and fieldwork information.

The results were associated to two groups of processes: artificial and natural. The natural processes can be influenced by the human activities, but they are unintentional. The artificial processes are intentional as works and beach regenerations. The natural processes usually are related with erosion and sediment dynamics on the coast.

\section{RESULTS}

All the spatial units were obtained by using QGIS map project and measured their area. After that, the work was centred in diversification between urban and non-urban places. Using the WMS from the ICV, it was selected the layer of land classify, in the official land planning [16]. After that, there have been selected only the spatial units considered inside the urban areas. 
Table 1: Summary of coastal changes in Torrevieja.

\begin{tabular}{|c|c|c|}
\hline Land Cover & Change process & $\Delta$ Area (ha) \\
\hline \multirow[t]{3}{*}{ Beach } & Artificial & 1.22 \\
\hline & Natural & -2.61 \\
\hline & Balance & -1.40 \\
\hline Breakwater & Artificial & 0.13 \\
\hline Port areas & Artificial & 16.05 \\
\hline Promenades & Artificial & 1.00 \\
\hline Rocky platform & Natural & -0.34 \\
\hline Sparsely vegetated areas & Natural & -0.21 \\
\hline \multirow{2}{*}{$\begin{array}{l}\text { Total } \\
\text { Total }\end{array}$} & Artificial & 18.39 \\
\hline & Natural & -3.16 \\
\hline \multicolumn{2}{|c|}{ Balance } & 15.23 \\
\hline
\end{tabular}

\subsection{Torrevieja}

The urban model is intensive in the city centre, and opener in the periphery, especially in La Mata neighborhood. Torrevieja had an estimated population in 1956 around 9,396 inhabitants. In the year 2014, the population growth up to 91,415. The population increase would be around 82,019 people. According to the coastal surface, Torrevieja has a total balance of 15.23 ha reclaimed from the sea. The artificial processes have generated an increase of 18.39 ha whereas the natural processes have generated a decrease of 3.16 ha. The most representative change has occurred in the Port of Torrevieja. These data can be seen in the Table 1 .

\subsection{Santa Pola}

Santa Pola has two important urban separated areas: Santa Pola centre and Gran Alancant. Nevertheless, Gran Alacant is far enough from the coast and no consider it in the study area. The urban model of Santa Pola is intensive in the city centre, and opener in the periphery, especially in Gran Playa, Playa Lisa and Santa Pola del Este. Santa Pola had an estimated population in 1956 around 6,252 inhabitants. In the year 2014, the population growth up to 31,529 inhabitants. The population increment would be around 25,277 people. Santa Pola has a total balance of 18.94 ha of surface reclaimed from the sea. The artificial processes have generated an increase of 21.93 ha whereas the natural processes have generated a decrease of 2.99 ha. The most representative change has occurred in the Port of Santa Pola (Table 2).

\subsection{Alicante}

Alicante is the biggest city and the capital of the province. Alicante has three urban districts near the coast: Urbanova, the city centre, and Cabo de las Huertas-Playa de San Juan. The urban model of Alicante is intensive in all the coastal districts. Alicante had an estimated population in 1956 around 113,816 inhabitants. In the year 2014, the population was of 332,067 inhabitants. The population increase would be around 218,251 people. According to the coastal surface, Alicante has a total balance of 150.07 ha of surface reclaimed to the sea. 
Table 2: Summary of coastal changes in Santa Pola.

\begin{tabular}{|c|c|c|}
\hline Land cover & Change process & $\Delta$ area (ha) \\
\hline \multirow[t]{3}{*}{ Beach } & Artificial & 9.62 \\
\hline & Natural & -2.99 \\
\hline & Balance & 6.64 \\
\hline Breakwater & Artificial & 1.49 \\
\hline Port areas & Artificial & 9.96 \\
\hline Urban fabric & Artificial & 0.79 \\
\hline \multirow[t]{4}{*}{ Water courses } & Artificial & 0.06 \\
\hline & Artificial & 21.93 \\
\hline & Natural & -2.99 \\
\hline & & 18.94 \\
\hline
\end{tabular}

Table 3: Summary of coastal changes in Alicante.

\begin{tabular}{|c|c|c|}
\hline Land cover & Change process & $\Delta$ area $($ ha) \\
\hline Beach & Artificial & 19.89 \\
\hline Beach & Natural & -1.59 \\
\hline Beach & Balance & 18.30 \\
\hline Breakwater & Artificial & 0.42 \\
\hline Port areas & Artificial & 121.97 \\
\hline Sparsely vegetated areas & Artificial & 3.13 \\
\hline Urban fabric & Artificial & 5.04 \\
\hline Water courses & Artificial & 1.21 \\
\hline \multicolumn{2}{|r|}{$\begin{array}{c}\text { Artificial } \\
\text { Natural }\end{array}$} & $\begin{array}{c}151.66 \\
-1.59 \\
\end{array}$ \\
\hline \multicolumn{2}{|c|}{ Balance } & 150.07 \\
\hline
\end{tabular}

The artificial processes have generated an increase of 151.66 ha whereas the natural processes have generated a decrease of 1.59 ha. The most representative change has occurred in the Port of Alicante, with 116.83 ha. These data can be seen in the Table 3.

\subsection{El Campello}

El Campello has several urban districts near to the coast: Playa Muchavista, the town centre, Coveta Fumà and Pueblo Acantilado-La Merced-Venta Lanuza. The urban model of El Campello is intensive only in the centre and much of its urban area is composed by open planning or suburbs. El Campello had an estimated population in 1956 around 3,657 inhabitants. In the year 2014, the population growth up to 27,081 . The population increase would be around 23,424 people. El Campello has a total balance of 30.24 ha gained to the sea. The artificial processes have generated an increase of 31.36 ha whereas the natural processes have generated a decrease of 1.12 ha. The most representative increment has occurred in the Muchavista Beach with 19.16 ha due to artificial regenerations (Table 4). 
Table 4: Summary of coastal changes in El Campello.

\begin{tabular}{|c|c|c|}
\hline Land cover & Change process & $\Delta$ area \\
\hline Beach & Artificial & 24.23 \\
\hline Beach & Natural & -0.60 \\
\hline Beach & Balance & 23.63 \\
\hline Breakwater & Artificial & 0.72 \\
\hline Port areas & Artificial & 6.24 \\
\hline Port areas & Natural & 0.90 \\
\hline Port areas & Balance & 7.13 \\
\hline Sparsely vegetated areas & Artificial & 0.17 \\
\hline Sparsely vegetated areas & Natural & -0.13 \\
\hline Sparsely vegetated areas & Balance & 0.04 \\
\hline Water courses & Natural & -1.29 \\
\hline $\begin{array}{l}\text { Total } \\
\text { Total }\end{array}$ & $\begin{array}{c}\text { Artificial } \\
\text { Natural }\end{array}$ & $\begin{array}{l}31.36 \\
-1.12\end{array}$ \\
\hline Balan & & 30.24 \\
\hline
\end{tabular}

\subsection{Villajoyosa}

Villajoyosa has diverse urban areas near the coast: to south, there are a urban zone occupied by hotels, new buildings and some houses, the centre is the intensive planning area and $L a$ Cala district is too far the coast because the beach on the zone belongs to another municipality (Finestrat). Villajoyosa had an estimated population in 1956 around 10,409 inhabitants. In the year 2014, the population growth up to 33.951 inhabitants. The population increase would be around 23,542 people. Villajoyosa has a total balance of 3.69 ha of land gain to the sea. The artificial processes have generated an increase of 9.32 ha whereas the natural processes have generated a decrease of 5.63 ha. Villajoyosa has an increase and decrease, more balanced than the previous municipalities. The most representative increase has occurred in the Port of Villajoyosa with 4.23 ha (Table 5).

\subsection{Altea}

The entire coast of Altea is urbanized. However, there are different intensities in land urbanisation. In the town centre, there is an intensive built area and in around, there are open planning areas and suburbs. Altea had an estimated population in 1956 around 5,854 inhabitants. In the year 2014, the population growth up to 22,518 . The population increase would be around 16,664 people. Altea has a total balance of 4.79 ha of land gain to the sea. The artificial processes have generated an increase of 13.03 ha whereas the natural processes have generated a decrease of 8.24 ha. The most representative increase has occurred in the Campomanes or Marina Greenwich Port with 3.64 ha. 
Table 5: Summary of changes in Villajoyosa.

\begin{tabular}{|c|c|c|}
\hline Land cover & Change process & $\Delta$ area ha. \\
\hline Beach & Artificial & 4.00 \\
\hline Beach & Natural & -5.28 \\
\hline Beach & Balance & -1.27 \\
\hline Breakwater & Artificial & 0.41 \\
\hline Port areas & Artificial & 4.23 \\
\hline Sparsely vegetated areas & Artificial & 0.48 \\
\hline Water courses & Artificial & 0.19 \\
\hline Water courses & Natural & -0.31 \\
\hline Water courses & Balance & -0.12 \\
\hline \multirow{3}{*}{$\begin{array}{l}\text { To } \\
\text { To } \\
\text { Ba }\end{array}$} & Natural & -0.03 \\
\hline & $\begin{array}{c}\text { Artificial } \\
\text { Natural }\end{array}$ & $\begin{array}{c}9.32 \\
-5.63\end{array}$ \\
\hline & & 3.69 \\
\hline
\end{tabular}

Table 6: Summary of changes in Altea.

\begin{tabular}{|c|c|c|}
\hline Land cover & Change process & $\Delta$ area ha \\
\hline Beach & Natural & -3.30 \\
\hline Breakwater & Artificial & 2.73 \\
\hline Port areas & Artificial & 6.77 \\
\hline Sparsely vegetated areas & Artificial & 1.28 \\
\hline Urban fabric & Artificial & 2.12 \\
\hline Water courses & Artificial & 0.14 \\
\hline Water courses & Natural & -1.65 \\
\hline Water courses & Balance & -1.51 \\
\hline \multicolumn{2}{|r|}{$\begin{array}{c}\text { Artificial } \\
\text { Natural }\end{array}$} & $\begin{array}{r}13.03 \\
-8.24 \\
\end{array}$ \\
\hline \multicolumn{2}{|c|}{ Balance } & 4.79 \\
\hline
\end{tabular}

\section{DISCUSSION}

The following table shows a resume of the results (Table 7). It is important to notice that an increment of coastal area gained to the see was produced in all the urban areas studied. This means that the expansion of these coastal cities was done not only occupying inland and transforming old houses into new buildings. A process of gaining land to the sea was noticed.

Comparing the increments of population and the increment of land occupied to the sea, there is no direct relation and this can reflect a different model of coastal occupation and the changes in these towns. 
Table 7: Population and land increase (1957 and 2014).

\begin{tabular}{|l|c|c|c|c|}
\hline Location & $\begin{array}{c}\text { Population } \\
1957\end{array}$ & $\begin{array}{c}\text { Population } \\
2014\end{array}$ & $\begin{array}{c}\Delta \text { Population } \\
\text { (inhabitants) }\end{array}$ & $\begin{array}{c}\Delta \text { Coastal } \\
\text { surface (ha) }\end{array}$ \\
\hline Alicante & 113,816 & 332,067 & 218,251 & 150.07 \\
\hline El Campello & 3,657 & 27,081 & 23,424 & 30.24 \\
\hline Santa Pola & 6,252 & 31,529 & 25,277 & 18.94 \\
\hline Altea & 5,854 & 22,518 & 16,664 & 4.79 \\
\hline Torrevieja & 9,396 & 91,415 & 82,019 & 15.23 \\
\hline Villajoyosa & 10,409 & 33,951 & 23,542 & 3.69 \\
\hline
\end{tabular}

Two models of growth may be reflected in these towns: the growth of urban area in general and the growth centred in the coast. The second one may be based on the tourism activity.

The natural processes produce negative changes, diminishing the coastal areas. In general, the erosion of the beaches and loss of sand seemed to be the main process. The sediments that have to feedback the beaches are relocated on other parts, especially alongside of the breakwaters. Nevertheless, part of the loss sand is not recovered. The breakwater effects and some beaches regeneration have avoided to the loss of the sand and in fact, the beaches. Their loss would have be a disastrous for tourism. The consequences of the beaches erosion, especially on urban beaches, affect on the one hand to the tourism, but on the other hand affect to the safety of the people and their belongings. To have a safe coast may be the main reason to protect the coastal line and regenerated the beaches. They act as defences of the coastline and infrastructure.

\section{CONCLUSION}

In all the cases studied, the natural processes lead to lose area of coast (shoreline) and the artificial processes gives coast area gain (positive increment).

Related to artificial processes, there is an important increment in harbour areas. In most of the cases, the port areas are located close to the town centre. The cause is the extension of the ports seems to be related to the tourism activities, fishing activities and commercial requirements. Moreover, there are new ports built during the period of the study. The second cause of the increase of urban coastal areas, gaining surface to the sea, is the beaches regeneration and transformation (for instance, changing gravel beaches to sand beaches).

The natural balance is negative. However, due to the artificial works, the global balance reflects an increment of coastal zone occupation due to land-to-sea gain.

The urban sand beaches are the more vulnerable spaces. The marine dynamics, coastal storms, floods and the construction over the previous dunes, impede the recovery of the sand. As a general conclusion, the man action, infrastructures, not only avoid a natural reduction of the coastal area in the towns analysed. Moreover, the global balance was an increment of the occupation of sea areas.

[1] Vidal, C., Losada, M.A., Medina, R. \& Losada, I., Modelos de Morfodinámica de Playas. Ingeniaría del Agua, 2, pp. 55-74, 1995.

[2] Tros-de-Ilarduya, F., West sea storms and Atlantic depressions in the province of Alicante: the case of Benidorm. Estudios Geográficos, 74, pp. 287-310, 2013.

[3] Portela-Bens, S., Cabrera Castro, R., Laiz, I., Gallego García, R.J. \& del Río, L., Personas exposure to Acercando el Mar y el Medio Ambiente. I Semana de la Ciencia. Temporales e inundaciones costeras en el marco del cambio climático. 
[4] Vallega, A., Geography, oceans and coasts towards sustainable development. Agenda 21 of Ocean Geography. pp. 17-113, 1998.

[5] Cori, B., Spatial dynamics of Mediterranean coastal regions. Journal of Coastal Conservation, 5, pp 105-112, 1999.

[6] Vallejo Pousada, R., Economía e historia del turismo español del siglo XX. Historia Contemporánea, 25, pp. 203-232, 2002.

[7] Tent-Maclús, J.E., Coast line change in the Bajo Segura (South of Alicante) in the last 15,000 years. Estudios Geográficos, 74, pp. 683-702, 2013.

[8] Mira I Botella, F., Repoblación de las dunas de Guardamar del Segura: Memoria y Láminas. Facsímil. Ilmo. Ayuntamiento de Guardamar del Segura, 1995.

[9] Larrabeiti Rodríguez, J.J., Producción de Nuevas "Naturalezas Urbanas" y sus Consecuencias sobre el Consumo de Agua en Alicante. Investigaciones Geográficas, 58, pp. 143-170, 2013.

[10] Juarez Sánchez-Rubio, C., Asignación de recursos de agua para uso agrario y crecimiento económico en la comarca meridional agraria de Alicante. Estudios Agrosociales y Pesqueros, 202, pp. 135-166, 2004.

[11] Calleja Sánchez, R., Navarro Hevia, J., Aldeguer Sánchez, M. \& Pérez Pérez, J., Estudio sobre el Estado de Degradación y Mejora del Pinar que Fija las Dunas de Guardamar del Segura. U.D. de Hidráulica e Hidrología. E.T.S.I. Agrarias. Universidad de Valladolid, 2005.

[12] Padilla, A., Colonización Vegetal en los Campos de Cultivo Abandonados en la Provincia de Alicante. Doctoral thesis, 1997.

[13] Olcina cantos, J. \& Torres Alfonsea, F.J., Incidencia de los temporales de levante en la ordenación del territorio alicantino. Papeles de Geografía, 26, pp. 109-136, 1997.

[14] Agboola, A.M. \& Ayanlade, A., Sea level rise and its potential impacts on coastal urban area: A case of Eti-Osa, Nigeria. Annals of the University of Oradea Geography Series, 23, pp. 188-200, 2016.

[15] PNOA histórico., Plan Nacional de Ortofotografía Aérea (PNOA). Plan Nacional de Observación del Territorio. Instituto Geográfico Nacional (IGN). http://pnoa.ign.es/ pnoa-historico.

[16] Instituto Cartogáfico Valenciano, zona de descargas. ordenación del territorio. http://www.icv.gva.es/auto/aplicaciones/icv_geocat/\#/results. 